From Japanese Colony to Sacred Chinese Territory: Taiwan's Geostrategic Significance to China

\title{
STEVE TSANG
}

SOAS China Institute, UK

Twentieth Century China, 45-3 (October 2020)

This paper shows that while China now attaches geostrategic importance to Taiwan, it has not always done so. It has only accorded such significance to Taiwan in the post-Mao era. By reviewing how Taiwan became a Japanese colony, how it came under the control of Chiang Kai-shek's government, and how it came to be seen by the government of the People's Republic of China as a sacred territory before being deemed geostrategically significant, this paper seeks to demonstrate that Taiwan's importance to China is not based on geography, an immutable factor. Instead, it was the result of contingencies of history and the changed calculations of succeeding governments in China. This leads to the important conclusion that the geostrategic importance the Chinese government now attaches to Taiwan may change if the Chinese leadership alters its strategic calculus or if the government itself is replaced. KEYWORDS: Cairo Conference, first island chain, imagined geography, sacred territory, strategic calculation

Since the People's Republic of China (PRC) describes Taiwan as a "sacred territory" in its constitution, it is reasonable to assume that it attaches central importance to Taiwan. ${ }^{1}$ The

\footnotetext{
${ }^{1}$ National People's Congress of the PRC, Constitution of the People's Republic of China, accessed September 12, 2016, http://www.npc.gov.cn/englishnpc/Constitution/2007- 
PRC government now further considers Taiwan of geostrategic importance, for which the late political scientist Alan Wachman gave intellectual underpinning. ${ }^{2}$ The description of a particular territory as "sacred" cannot imply other territories not so labelled are not. It is, therefore, essentially political rhetoric and can be dropped should there be a change of regime, government, or even priorities. The same applies, perhaps to a lesser extent, to the strategic value attributed to a territory. Whether a territory is of strategic importance or not is ultimately a judgment of a government based on its intentions and its assessment of the value of a territory to fulfill its priorities in matters of national security.

In contrast, geography is a constant rather than a variable factor. Geostrategic significance or strategic significance based on geography is generally deemed long-standing rather than ephemeral. Thus, a geostrategically important territory is one for which its strategic value is based primarily on its location and/or topography; it is a territory that is vital for the long-term security of the state. Thus, the geostrategic importance of, say, the Black Sea region to Russia, the Strait of Hormuz to Iran, or the Strait of Malacca to Malaysia or Indonesia is not dependent on who is in control of the respective countries. Consequently, a sovereign power, regardless of shifting party politics, is prepared to pay a substantial price to hold, defend, recover, or secure a geostrategically important territory. Even if a country is not in a position to hold or recover it, it will not refrain from making a commitment to do so.

The PRC's solemn pledge to use force if unavoidable to secure Taiwan regardless of risks and costs suggests that it does see geostrategic value in Taiwan. ${ }^{3}$ This can be seen to

\footnotetext{
${ }^{2}$ Alan M. Wachman, Why Taiwan? Geostrategic Rationales for China's Territorial Integrity (Stanford, CA: Stanford University Press, 2007), esp. 29-37.

3 "Jiang Zemin's Eight-Point Proposal," January 30, 1995, accessed September 12, 2016, http://www.gwytb.gov.cn/en/Special/Jiang/201103/t20110316_1789198.htm; "Chinese
} 
imply that whether the Chinese Communist Party (CCP) stays in control of China or not, the government of China will seek the incorporation of Taiwan.

This paper challenges the last point and posits that Taiwan's geostrategic importance to China, being relatively recent, is in reality contextually derived and dynamic rather than geographically determined and immutable. ${ }^{4} \mathrm{~A}$ territory is deemed to be strategically important or not primarily on the basis of its value for serving the strategic ambition of the government concerned, and that can change as the strategic objective or ambition or the security doctrine of the state shifts. Hence, while the PRC government has in the last three decades incorporated Taiwan's location into its calculation of the island's strategic value, its approach reflects that it still sees Taiwan's significance more in general strategic terms than in specific geostrategic terms.

This paper assesses Taiwan's geostrategic importance to China by examining the changing historical circumstances that transformed the island from a Japanese colony into the PRC's geostrategically important and "sacred" territory. It ascertains the prices successive governments in control of China were prepared to pay to secure Taiwan at various crucial points in history, particularly in 1895 , the 1940 s, the 1950 s, and since the 1980 s. It probes not

Premier Warns against ‘Taiwan Independence,'” Washington Post, March 16, 2000, accessed September 12, 2016, http://fas.org/news/china/2000/eng20000316N101.htm.

${ }^{4}$ Edward Friedman took the view that the PRC government has never put Taiwan at the top of its priority in security terms and has never shown any willingness to risk a war with the United States over Taiwan. Edward Friedman, "Peace or War with Taiwan in China's Foreign Policy," in Jon Sullivan and Chun-yi Lee, eds., A New Era in Democratic Taiwan: Trajectories and Turning Points in Politics and Cross-Strait Relations (Abingdon, UK: Routledge, 2018), 123-41. 
only the roles played by the CCP but also that played by the Guomindang (GMD) in this process of transformation. It contests the premise that the PRC's approach has always been governed by geostrategic considerations and shows that this only became a significant consideration in the post-Mao period. This paper also puts forth the case that changes in overall capabilities and strategic conception were responsible for Beijing's understanding of Taiwan's geostrategic value.

$<$ A $>$ The Symbolism of the Treaty of Shimonoseki versus the Peripheral Significance of Taiwan

Notwithstanding Chinese official statements since 1950, Taiwan was, in fact, historically of peripheral importance to mainland China. The Manchus founded the Qing Empire in 1644 and took control of the rest of mainland China from the Ming Empire in 1650. But for another three decades it ignored Taiwan, then under the control of the family of Zheng Chenggong (鄭成功 1624-1662), a pirate of both Han and Japanese parentage who had seized Taiwan from the Dutch as the Ming Empire crumbled. This happened even though Zheng professed loyalty to the defunct Ming royal family. The fact that the Qing, one of the mightiest of empires in its time, did not attempt to take Taiwan for so long confirmed that Taiwan was not seen to be of great geostrategic value to it. It finally took Taiwan after the Zheng family unsuccessfully supported the rebellion of former Ming generals led by Wu Sangui (吳三桂 1612-1678) on the mainland. Indeed, after the Qing conquered Taiwan in 
1683 it administered Taiwan as a frontier region appended to Fujian province. ${ }^{5}$ The Qing government only elevated Taiwan to provincial status in 1885 in order to preempt foreign imperial ambition over the island. ${ }^{6}$ This policy failed as the Qing ceded Taiwan to Japan after losing a war over Korea to Japan a decade later. The defeat and the harsh terms of the Treaty of Shimonoseki (1895) unleashed forces for a republican revolution that brought down the Qing within two decades. ${ }^{7}$

There is no evidence that Qing substantially revised its view on the geostrategic importance of Taiwan in the nineteenth century. ${ }^{8}$ If Qing policy makers had started to see Taiwan as geostrategically vital, they would have deployed significant forces there, fortified it, or tried to avoid its cession. None of this happened. Qing's weakness vis-à-vis Japan did

\footnotetext{
${ }^{5}$ Bruce Jacobs argued that Taiwan was never Chinese since the Qing Empire was Manchu, and thus Taiwan, like China proper, was merely a Manchu colony. Bruce Jacobs,
} Democratizing Taiwan (Leiden: Brill, 2012), 19-23.

${ }^{6}$ Steve Tsang, "Putting Chinese Unity and the Relations between Taiwan and Mainland China into a Historical Context," in Gunter Schucher and Margot Schuller, eds., Perspective on Cross-Strait Relations: Views from Europe (Hamburg: Mitteilungen des Instituts fur Asienkunde, 2005), 21.

${ }^{7}$ Treaty of Shimonoseki (1895), accessed September 12, 2016, http://www.taiwandocuments.org/shimonoseki01.htm.

${ }^{8}$ Even Japan did not annex Taiwan because of its geostrategic importance. Victory in 1895 generated a popular demand for territorial acquisition, and Tokyo picked Taiwan primarily because it would not risk provoking an intervention from the Western powers and because its navy considered Taiwan useful. Edward I-te Chen, "Japan's Decision to Annex Taiwan: A Study of Ito-Mutsu Diplomacy, 1894-95," Journal of Asian Studies 37, no. 1 (1977): 61-72. 
not stop it from working to stop the cession of Liaodong (遼東), also demanded by Japan.

The Qing worked with Russia, France, and Germany to avert the loss of Liaodong — which was strategically located for maritime access to Beijing - by substantially increasing the indemnity to Japan. It did not attempt the same for Taiwan. Indeed, when the Taiwanese resisted Japanese occupation, the Qing government offered them no help, though some Chinese ignored government policy and went to Taiwan to join the resistance. ${ }^{9}$ The reality was that cession of Taiwan, geographically remote from Beijing, was treated in a way not fundamentally different from the treatment of Hong Kong half a century earlier. There is no evidence to suggest Beijing saw greater value in Taiwan's geography and strategic value in 1895 than it had seen in those of Hong Kong when it ceded it to Britain.

Changes in military technologies and strategic goals of states affect how a territory is evaluated in terms of its geostrategic value, and it is tempting to make such a case retrospectively. The geostrategic significance Taiwan could have for China in the late twentieth century and the early twenty-first century was not recognized by the government in control of China a century or half a century earlier.

The real significance of the Treaty of Shimonoseki for China was that it marked a turning point in its modern history. What galvanized Chinese intellectuals and officials to attempt basic reforms or a revolution was not the loss of a geostrategically vital territory called Taiwan but the demonstrated incapacity of the Qing to respond to challenges mounted by a modernizing Asian neighbor it had previously considered inferior. The treaty showed the bankruptcy of Qing's earlier reforms and unleashed forces that led to its collapse.

\footnotetext{
${ }^{9}$ Li Xiaofeng and Lin Chengrong, Taiwan shi [History of Taiwan] (Taipei: Huali tushu, 2003), 149-59.
} 
The reality was that Taiwan did not figure strongly in China's national imagination prior to the start of the Pacific War in 1941. Historian Steven Philips was right that "from 1895 until the late 1930s, no Chinese government—Qing Empire, Nationalist Republic, or Communist Soviet — had a realistic chance of restoring sovereignty over the island, and no leader of these entities made Taiwan a major issue in domestic politics or relations with Japan." ${ }^{10}$ But if Taiwan had been of real geostrategic importance, its eventual recovery would have been made into a nationalist rallying cry. It was not. Historian Shi-chi Mike Lan also has demonstrated persuasively that while there were incidental narratives in China that referred to the Taiwanese as compatriots, the mainstream view across the spectrum saw Taiwan as separate from China, generally in terms not much different from that of the former vassal state Korea. ${ }^{11}$ Taiwan was not part of China's "imagined geography" in this period. ${ }^{12}$ Even those who considered the Taiwanese to be compatriots saw a "Taiwanese independence movement" and a "Taiwanese national liberation movement" as "efforts of the Taiwanese, by the Taiwanese, and for the Taiwanese." ${ }^{13}$ Taiwan's status as a Japanese colony was widely

\footnotetext{
${ }^{10}$ S. E. Phillips, "Confronting Colonization and National Identity: The Nationalists and
} Taiwan, 1941-45," Journal of Colonialism and Colonial History 2, no. 3 (2001): 2.

${ }^{11}$ Shi-chi Mike Lan, "The Ambivalence of National Imagination: Defining 'The Taiwanese' in China, 1931-1941," China Journal, no. 64 (July 2010): 179-97.

12 This concept is borrowed from Emma Jinhua Teng, Taiwan's Imagined Geography: Chinese Colonial Travel Writing and Pictures, 1683-1895 (Cambridge, MA: Harvard University Press, 2004).

${ }^{13}$ Lan, "Ambivalence of National Imagination," 195. 
accepted in China prior to the Pacific War, just like Hong Kong's status as a British colony. ${ }^{14}$ No leader of China saw Taiwan as worth a significant price.

The CCP's position was summed up by Mao Zedong when he met with the American journalist Edgar Snow in the 1930s. ${ }^{15}$ Mao stated that "it is the immediate task of China to regain all our lost territories," but he specified that the CCP did "not, however, include Korea, formerly a Chinese colony" and that "the same thing applies for Taiwan." ${ }^{16}$ Until then, there had been only one occasion on which a senior CCP leader had articulated a different view. In an essay about human races and the international Communist movement published in 1924, Li Dazhao (李大釗)wrote that in light of shared history and culture Taiwan "should not be separated from the Chinese nation." ${ }^{17}$ This was an aberration, never repeated or adopted as party policy.

The first time the CCP addressed Taiwan as a policy issue was at its Sixth National Congress in 1928. This occurred three months after the Taiwan Communist Party (TCP) was formed by nine Taiwanese on April 14, $1928 .^{18}$ The TCP manifesto specified that the

${ }^{14}$ On the case of Hong Kong, see Steve Tsang, Hong Kong: An Appointment with China (London: I.B. Tauris, 1997), 17-33.

${ }^{15}$ Frank Hsiao and Lawrence Sullivan, "The Chinese Communist Party and the Status of Taiwan, 1928-1943," Pacific Affairs 52, no. 3 (1979): 446-67.

${ }^{16}$ Edgar Snow, Red Star Over China (Hammondsworth, UK: Pelican, 1972), 128.

${ }^{17}$ Li Dazhao, Li Dazhao wenji [Collected works of Li Dazhao], vol. 2 (Beijing: Renmin chubanshe, 1984), 766.

${ }^{18}$ Gao Mingshi, ed., Taiwan shi [Taiwan history] (Taipei: Guojia tushuguan, 2009), 199. 
organization was to be a subchapter of the Japanese Communist Party (JCP) and advocated the independence of Taiwan. ${ }^{19}$

Adhering closely to the position of the Comintern, the CCP embraced the TCP as a subset of the JCP and supported Taiwanese and Korean independence. ${ }^{20}$ The CCP described "the Taiwanese in Fujian" as a minority nationality alongside the Mongols, Hui, Manchus, Koreans, Miao, Li, and peoples of Xinjiang and Tibet. ${ }^{21}$

Mao's statement to Snow merely reflected the position of the Comintern. Taiwan was not a controversial issue within the fractious CCP. Its leadership did not see potential geostrategic significance in Taiwan. When the CCP negotiated with the GMD to form the United Front at the start of the War of Resistance against Japan in 1937, Zhou Enlai talked about working with the Taiwanese and the Koreans against Japanese oppression. ${ }^{22}$ Zhou

${ }^{19}$ Lu Xiuyi, Riju shidai Taiwan gongchandang shi [History of the Communist Party of Taiwan in the era of Japanese rule] (Taipei: Qianwei chubanshe, 1989), 211-17. ${ }^{20}$ Resolution of the CCP Central Committee, 25 December 1935, in Zhongyang wenxian yanjiushi [Central Documentary Research Office], comp., Zhonggong zhongyang wenjian xuanji [Selected documents of the Party Central of the CCP] (Beijing: Zhongyang dangxiao chubanshe, 1991), vol. 7, 772 .

${ }^{21}$ Resolution on the nationality problem, 9 July 1928, in Zhonggong zhongyang wenjian xuanji, vol. 4, 388. The CCP was not exceptional in this; Chinese newspapers in the early twentieth century often saw Taiwanese and other minorities in not dissimilar terms. 22 Telegram from Zhou Enlai, 2 May 1937, 080104-009, 08A-01391, Tejiao dang'an [Archives on special missions], Chiang Kai-shek Papers, Academia Historica, Taipei. On the start of the war and how Chiang reached a decision on the United Front, see Steve Tsang 
again treated Taiwan as an external partner in 1941 in an article in Xinhua ribao (新华日报 New China daily), which stressed that the Chinese nation should work with the anti-Japanese movement in Taiwan as well as the anti-German movements in the Balkans and Africa. ${ }^{23}$

Until the Pacific War started in December 1941, the CCP's position on Taiwan was not different from that of the GMD or from the general sentiments of the country. Little was said about Taiwan. Even Chiang Kai-shek, whose views during the war would bring about a basic change to Chinese policy, was largely silent on Taiwan beforehand.

The first time Chiang raised the issue was as the War of Resistance was raging. He did so in a speech about the future of the GMD and China's resistance, at a conference of GMD national representatives on April 1, 1938, after losing strategically important parts of northern and eastern China. The speech was meant to boost morale in the midst of the crucial Battle of Taierzhuang (臺兒莊). There Chinese forces fought ferociously to stop Japan’s military, which was building up momentum after capturing Shanghai and Nanjing. ${ }^{24}$ Chiang

"Chiang Kai-shek's 'Secret Deal' at Xian and the Start of the Sino-Japanese War," Palgrave Communications 1, no. 1 (2015): 7-8.

${ }^{23}$ Zhou Enlai, "Minzu zhishang guojia zhishang," Xinhua ribao [New China daily], June 15, $1941,1$.

${ }^{24}$ Taierzhuang was not a great battlefield success: it merely disabled one Japanese division. But stopping the Japanese military momentum eased pressure on Chiang to surrender and was very significant. Li Zongren and Tang Degang, Li Zongren huiyilu [Memoirs of Li Zongren] (Hong Kong: Nanyue chubanshe, 1986), 479-80. 
declared that the GMD should strive to "recover Korea and Taiwan." 25 While the articulation of this ambition was noteworthy, Chiang still emphatically put Taiwan in the same category as Korea.

$<$ A $>$ Beginning of a Change in Attitude

The start of the Pacific War, marked by Japan's attack on Pearl Harbor, fundamentally changed the context in which Chiang looked at the war. Chiang saw it as presenting "an opportunity of a thousand years." ${ }^{26}$ He promptly declared war on Japan, something he had desisted from doing for four years, and worked to forge an alliance with the great powers led by the United States. ${ }^{27}$ Chiang linked the wars in East Asia, Europe, and elsewhere into a global conflict. ${ }^{28} \mathrm{He}$ saw this as a turning point that would enable China to emerge as one of the victors, after barely managing to survive the Japanese onslaught. He started to think about war goals beyond avoiding defeat.

${ }^{25}$ Qin Xiaoyi, comp., Zhongtong Jianggong sixiang yanlun zhongji [Complete collection of the thoughts and words of President Chiang Kai-shek] (Taipei: Zhongguo guomindang zhongyang weiyuanhui dangshi weiyuanhui, 1984), vol. 15, 186-88. Chiang did note that Korea was a former vassal, whereas Taiwan had been part of China.

${ }^{26}$ [Instructions on our policy in the Pacific War], 8 December 1941, 080103-055, 08A01311, Tejiao dang'an, Chiang Kai-shek Papers, Academia Historica, Taipei.

27 "Shilüe gaoben" [Brief draft chronicle of events], entry for 8 December 1941, Chiang Kaishek Papers, Academia Historica, Taipei.

28 "Jiang Jieshi riji" [Chiang Kai-shek's diary], entry for 9 December 1941, Hoover Institution, Stanford University. 
Contrary to popular belief, Chiang did not declare war on Japan intending to wait for the Allied powers to crush Japan. He sought to gain access to the vast resources of the Allies. ${ }^{29}$ He hoped victory would make China a partner with the great powers and end the unequal treaties. ${ }^{30}$ It was with this in mind that he ordered the most powerful strategic reserve, which became the Chinese Expeditionary Force, not to reinforce Changsha against a formidable Japanese assault but to help Britain hold Burma, with a separate force sent to assist the British defense of Hong Kong. ${ }^{31}$ Securing Burma also served a strategic interest, as it was the last land route the United States could employ to supply China. ${ }^{32}$ To Chiang, demonstrating Chinese military prowess in front of the Allied powers was at least as important as keeping the Burma Road open. In the end, the Burma Campaign cost China

29 "Shilüe gaoben," entry for 13 December 1941.

${ }^{30}$ He Husheng, Banian Kangzhan zhong de Jiang Jieshi [Chiang Kai-shek in the midst of the eight-year War of Resistance] (Taipei: Fengyun chubanshe, 2011), 287-88; "Jiang Jieshi riji," entry for 20 December 1941.

${ }^{31}$ Britain lost Hong Kong before the Chinese relief column could reach Hong Kong. The Expeditionary Army consisted of three corps, including the last partially motorized elite corps (the Fifth and Sixth) that incorporated the only mechanized division (the 200th). Various telegrams from Chiang to Stilwell, 080103-055, 08A-01312, Tejiao dang'an, Chiang Kai-shek Papers, Academia Historica, Taipei. Among all Allied forces in Burma, the Chinese put up the toughest fight.

${ }^{32}$ Xie Hingyu, Ying yang guo wei [Showing off national strength like an eagle] (Taipei:

Dongda tushu gongshi, 1997), 53. 
dearly, ${ }^{33}$ as its only strategic reserve that had tanks and substantial artillery to give it offensive capacity was largely lost and the land route to India was closed. Consequently, Chiang's forces could not mount another major offensive until the Second Burma Campaign was launched from India in 1944 by a new army raised, trained, and equipped by the United States in India.

The incapacity of China to attack aggressively undermined Chiang's scope to persuade the Allies to accommodate his wartime demands. Notwithstanding the ebb and flow of military fortune, Chiang started to review his options. His thinking on Taiwan and other former Chinese dependencies evolved as China's fortune and standing changed during the war. The process started after China declared war on Japan in December 1941, at which point the Chinese government considered all previous bilateral treaties between them null and void. $^{34}$

The prospect that China would win affected how senior GMD figures spoke about Taiwan. Some echoed Chiang's optimism and articulated a new ambition. The first manifestation happened at a public rally in April 1942 organized by a small Taiwanese group loosely affiliated with the GMD, the Taiwan Geming Tongmenghui (臺灣革命同盟會),

${ }^{33}$ The Chinese casualty figure is under dispute. The official history suggests it was roughly 60,000 of a deployed force of 100,000. Huang Daoxuan has suggested it was closer to 40,000 of a deployed force of 70,000. Huang Daoxuan, "Miandian zhangyi Jiang Jieshi, Shi Diwei de Shibai zeran" [Responsibility for failure between Chiang Kai-shek and Stilwell in the Burma Campaign], Kangri zhanzheng yanjiu [Research into the War of Resistance against Japan] 2 (2001): 128-30.

${ }^{34}$ [Draft declaration of war against Japan], December 1941, 080101-015 08A-00069, Tejiao dang'an, Chiang Kai-shek Papers, Academia Historica, Taipei. 
which advocated that Taiwan should rejoin China. The president of the Legislative Yuan, Sun Ke (孫科 1891-1973), explained that while there had been hitherto no prospect that Taiwan could be recovered he now felt confident that China would defeat Japan and would then welcome Taiwan to rejoin mother China. ${ }^{35}$ But he did not see the recovery of Taiwan as a matter of strategic importance or indicate a willingness to pay a price for it. Senior general Feng Yuxian (馮玉祥 1882-1948) went further and stressed that China could and should do so by working with the Allied powers. ${ }^{36}$ The government news agency, Central News, gave positive coverage, which was carried not only in GMD-friendly newspapers but also in the Communist Xinhua ribao. ${ }^{37}$ This happened at the only time when China stood relatively tall among the Allies during the war. Chiang's forces had just repulsed the Japanese advance on Changsha, the Chinese Expeditionary Force had outperformed the British in Burma, and the United States had not yet launched the Doolittle Raid — the first counterattack after Pearl Harbor. The articulation of such views was noteworthy but did not amount to a policy change.

${ }^{35}$ Sun Ke, "Jiefang yizai muqian le" [Liberation is in sight], in Zhang Ruicheng, Kangzhan shiqi shoufu Taiwan zhi zhongyao yanlu [Important speeches on recovering Taiwan during the War of Resistance against Japan] (Taipei: Guomingtang zhongyang weiyuanhui, 1990), 22.

${ }^{36}$ Feng Yuxian, "Women yao ganjin shoufu Taiwan" [We should recover Taiwan without delay], Zhang, Kangzhan shiqi shoufu Taiwan zhi zhongyao yanlun, 19.

${ }^{37}$ Xinhua ribao, April 5, 1942. 
While the Communist-controlled media reported such activities positively, ${ }^{38}$ no senior CCP leader departed from the standard Comintern position. The CCP Central Committee reaffirmed its long-standing position by referring to the Taiwanese together with the Koreans and Vietnamese in one breath, and it supported their struggle for independence on the day China declared war on Japan. ${ }^{39}$ It continued to refer to "the Chinese, the peoples of the Southern Ocean, the Korean people, and the Taiwanese people" in its declaration to commemorate the sixth anniversary of the start of the War of Resistance, in July $1943 .{ }^{40}$ There is no record of the CCP modifying its position on Taiwan prior to the Cairo Conference.

$<$ A $>$ All Change at Cairo

By October 1942 Chiang had adjusted his thinking on Taiwan and other Chinese territories that Japan had seized from China. ${ }^{41}$ This followed his engagement with the Western powers

${ }^{38}$ Liu Xiaoyuan, A Partnership for Disorder: China, the United States and Their Policies for the Postwar Disposition of the Japanese Empire 1941-1945 (Cambridge: Cambridge University Press, 1966), 163.

${ }^{39}$ Zhonggong zhongyang guanyu taipingyang fanri tongyi zhanxian de zhishi [CCP Central's anti-Japanese United Front directives), Zhongyang wenxian yanjiushi, ed., Zhonggong zhongyang wenjian xuanji (Beijing: Zhongyang dangxiao chubanshe, 1991), vol. 13, 251. 40 Jiefang ribao [Liberation daily], July 2, 1943. I am grateful to Dr S.C. Yin for drawing my attention to the CCP position on Taiwan in 1942.

41 "Shilüe gaoben," entry for 6 October 1942. The Americans winning a decisive victory in the Battle of Midway no doubt reinforced Chiang's confidence of an Allied victory, but he had been confident of victory from the start of the Pacific War, as explained above. 
to negotiate the end of the "unequal treaties." ${ }^{42}$ His government sought the early return of Hong Kong's New Territories from Britain. When the Chinese requested American support over Hong Kong, the Americans declined because they needed British cooperation to win the war. Instead, they indicated readiness to see Japan retrocede Manchuria and Taiwan to China. ${ }^{43}$ It was this knowledge that gave Chiang confidence to include Taiwan on a list of lost territories he would like to recover when he met President Franklin Roosevelt. ${ }^{44}$ Chiang had not articulated any recognition of specific geostrategic value in Taiwan. ${ }^{45}$

Indeed, it was only on the last day of the Cairo Conference in November 1943 that Chiang asked for Taiwan. Cairo was one of many Allied wartime summits, though it was the only one in which China's leader took part. Roosevelt told Chiang that he wanted to forge a "full blown partnership of China, Great Britain, Russia and the US." 46 In reality, he was more

${ }^{42}$ John W. Garver, "China’s Wartime Diplomacy," in James Hsiung and Steven Levine, eds., China's Bitter Victory: The War with Japan, 1937-1945 (Armonk, NY: East Gate, 1992), 10. ${ }^{43}$ Telegram from Wellington Koo (London) to Chiang Kai-shek, 15 October 1943, 080106016, 08A-01509, Tejiao dang'an, Chiang Kai-shek Papers, Academia Historica, Taipei. ${ }^{44}$ Report of Guo Binkai, 20 December 1943, 080106-022, 08A-01533, Tejiao dang'an, Chiang Kai-shek Papers, Academia Historica, Taipei.

${ }^{45}$ In China's Destiny, a propaganda book issued in his name in 1943, Chiang did refer to all territories of the Qing Empire as organic parts of China as a whole that should be taken back. Wachman thought this suggested that Taiwan, among all "lost territories," was considered of geostrategic value. Wachman, Why Taiwan?, 80-81. Chiang's words were much too general to indicate he saw specific geostrategic value in Taiwan.

46 Telegram from Roosevelt to Chiang, 28 October 1943, 080103-057, 08A-01321, Tejiao dang'an, Chiang Kai-shek Papers, Academia Historica, Taipei. 
modest: he wanted "to buoy the ego and spirit of Chiang and to insure that China would not make a separate peace with Japan" and free up Japanese forces there for fighting the Americans elsewhere. ${ }^{47}$ The British prime minister, Winston Churchill, for his part, did not see much value in the meeting ${ }^{48} \mathrm{He}$ prioritized the invasion of France and went to Cairo to accommodate Roosevelt. ${ }^{49}$ For Chiang, this was a meeting of historic importance. ${ }^{50}$ For days he pondered over the most important issues to raise,${ }^{51}$ and on the day he left for Cairo he finally decided on the following, in order of importance:

a. The international political order;

b. The organization of the Far Eastern Commission;

${ }^{47}$ Ronald Ian Heiferman, The Cairo Conference of 1943: Roosevelt, Churchill, Chiang Kaishek and Madame Chiang (Jefferson, NC: McFarland, 2011), 2. Since the United States and the United Kingdom did not intend to provide the forces and materiel required for a major offensive in Burma, as Chiang requested, the risk that Chiang might negotiate with the Japanese for a separate peace became a concern to Roosevelt.

${ }^{48}$ Heiferman, Cairo Conference, 59.

${ }^{49}$ Andrew Roberts, Masters and Commanders: How Roosevelt, Churchill, Marshall and Alanbrooke Won the War in the West (London: Allen Lane, 2008), 425-30.

50 "Jiang Jieshi riji," entry for 7 November 1943 (reflections on previous week).

${ }^{51}$ For earlier discussions and the changing lists of key issues, see "Shilüe gaoben," entries for 12 and 14 November 1943, in particular gong pishijian (公批示见)dated 14 November 1943[Chiang's comments and instructions]; 080106-016, 08A-01509, Tejiao dang'an, Chiang Kai-shek Papers, Academia Historica, Taipei; Stilwell to Chiang, November 1943, 080106-021, 08A-01528, Tejiao dang'an, Chiang Kai-shek Papers, Academia Historica, Taipei. 
c. The formation of a combined chiefs of staff among China, Britain, and the United States;

d. A plan for managing occupied territories;

e. Planning for the counteroffensive in Burma;

f. The independence of Korea; and

g. Getting a promise for the return of Manchuria and Taiwan. ${ }^{52}$

It was only after he arrived in Cairo that Chiang realized this was a working meeting, and he adapted as best as he could. He now listed the securing of Allied naval and air support to reopen the Burma Road as the top priority, followed by the return of Manchuria, Taiwan, and the Pescadores, and followed further by other postwar settlement issues, including the independence of Korea and Thailand, as well as the transfer of Japanese assets and military hardware in China to his government. ${ }^{53}$ The summit proved a difficult one. All three leaders worked toward different priorities, and Chiang's main demand - for naval and air support for the Burma Campaign — was deemed unrealistic by the others.

Before the summit was over, Roosevelt realized that he needed to send Chiang home "with ammunition to solidify his position in the GMD hierarchy and reinforce his popularity with the Chinese people." ${ }^{54}$ Thus, even though four days of deliberation had failed to deliver a plan for the war in 1944, the summiteers took only an hour to draft and agree to a short press communique. ${ }^{55}$ It incorporated significant elements of an original Chinese text, which stipulated: "The territory that Japan has so treacherously stolen from the Chinese, such as

52 "Jiang Jieshi riji," entry for 18 November 1943.

53 "Jiang Jieshi riji," entry for 22 November 1943 (agenda for the week).

${ }^{54}$ Heiferman, Cairo Conference, 105.

55 "Shilüe gaoben," entry for 26 November 1943; Heiferman, Cairo Conference, 114. 
Manchuria and Formosa, and Bonnin Islands [sic], will of course be returned to the Republic of China. All of the conquered territory taken by violence and greed by the Japanese will be freed from their clutches." 56

The most important and pertinent part of the communique, which has since then been known as the Cairo Declaration, states:

It is their purpose that Japan shall be stripped of all the islands in the Pacific which she has seized or occupied since the beginning of the first World War in 1914, and that all the territories Japan has stolen from the Chinese, such as Manchuria, Formosa, and The Pescadores, shall be restored to the Republic of China. Japan will also be expelled from all other territories which she has taken by violence and greed. The aforesaid three great powers, mindful of the enslavement of the people of Korea, are determined that in due course Korea shall become free and independent. ${ }^{57}$

Although Chiang failed to secure the higher priorities he had set when he left for Cairo, he was satisfied. In his diary, he acknowledged that he had made the greatest achievements in the political sphere, highlighting in particular the promised return of Manchuria, Taiwan, and the Pescadores, as well as the independence of Korea. ${ }^{58}$

The future of Taiwan and the other named territories were decided by the summiteers not because of their strategic value but because it was the one compromise they could reach.

${ }^{56}$ China's original draft, 080106-021, 08A-01530, Tejiao dang'an, Chiang Kai-shek Papers, Academia Historica, Taipei.

57 “The Cairo Communique,” accessed October 4, 2016, http://www.ndl.go.jp/constitution/e/shiryo/01/002_46/002_46tx.html. 58 "Jiang Jieshi riji," entry for 26(?) November 1943 (reflections of the previous week). 
It happened because Roosevelt "believed that a display of generosity, gratuitous offerings of enemy territory to the Chinese ... would persuade Chiang to stay in the war against Japan." 59

As a wartime summit the Cairo conference did little to enable the Allied powers to refine their military strategy. It also did not help China's war efforts in getting support for the Burma Campaign, in significantly increasing the airlift of materiel to China, or in securing financial aid to ease pressure on the economy. But it remains a historically important event, since the final communique became the basis for successive Chinese governments to claim sovereignty over Taiwan. It came to be treated as the first wartime Allied "agreement" on the future of Taiwan (and, for that matter, Korea). After Cairo, Chiang worked on the assumption that Taiwan would be returned to China after the war and instructed his staff to start planning for its recovery. ${ }^{60}$ When Japan surrendered, he dispatched two corps to take over Taiwan. ${ }^{61}$ This raised no eyebrows in Washington, London, Yan'an, or Moscow, in none of which Taiwan was considered of strategic value.

The Chinese military occupation of Taiwan took place in accordance with Supreme Commander of the Allied Powers General Order No. One, issued by General Douglas MacArthur. ${ }^{62}$ Under international law, Taiwan's status would be determined at the peace conference, and Chinese forces merely occupied Taiwan temporarily on behalf of the Allied powers. Chiang's government worked on a different premise. It believed its declaration of

\footnotetext{
${ }^{59}$ John Paton Davies Jr., China Hand: An Autobiography (Philadelphia: University of Pennsylvania Press, 2012), 150.

60 "Shilüe gaoben," entry for 17 January 1944.

61 "Shilüe gaoben," entry for 10 October 1945.

62 "Supreme Commander of the Allied Powers General Order No. One," accessed October 5, 2016, http://www.taiwandocuments.org/surrender05.htm.
} 
war had nullified the Treaty of Shimonoseki. It thought it had resumed jurisdiction over Taiwan on the basis of the Cairo Declaration as well as Japan's signing of the instrument of surrender. ${ }^{63}$ A year later, Chiang intended to take advantage of what the Japanese had accomplished in Taiwan and the fact that it was free from Communist influence to make it into a model province. ${ }^{64} \mathrm{He}$ also used Taiwan's resources, be they agricultural produce or manpower, to support the civil war on the Chinese mainland. For two years or a bit longer after taking over Taiwan, Chiang did not expect to lose the Chinese Civil War and could not have planned to turn it into his last redoubt. Geostrategic value did not figure at this point.

$<$ A $>$ The CCP's Responses

The leading Communist-run newspapers applauded the Cairo Declaration when it was released. While Xinhua ribao and Jiefang ribao (解放日报 Liberation daily) expressed excitement and confidence of victory, their editorials merely mentioned the prospective

${ }^{63}$ Steve Tsang, The Cold War's Odd Couple: The Unintended Partnership between the Republic of China and the UK, 1950-1958 (London: I.B. Tauris, 2006), 64. Some may argue that, since Taiwan had been previously under Manchu and not Han Chinese jurisdiction, an end of Japanese sovereignty should imply returning Taiwan to Manchu jurisdiction. Since the Republic of China had become the successor state to the Qing Empire, it also inherited any right (and obligation) attributable to Qing. Thus, if Taiwan were not to become an independent state, sovereignty over it would revert to the Republic of China. 64 "Shilüe gaoben," entry for 26 October 1946. This was half a year before the February Twenty-eighth incident. 
return of Taiwan in passing. ${ }^{65}$ The Cairo Declaration did not result in a review of the CCP's position on Taiwan. Taiwan continued to come under the JCP, not the CCP. When the CCP Central sent an instruction to Deng Xiaoping in East China following Cairo, it merely warned Deng that Japan might retaliate militarily and urged Deng to be prepared. ${ }^{66}$ For a year the CCP did not adjust to the prospect that Taiwan could be recovered. It was not until the Seventh Party Congress of April 1945 that Mao mentioned Taiwan for the first time after Cairo. Even then, he did so in passing. He said that the conference made a "good decision, namely, that the four northeastern provinces, Taiwan, and the Pescadores should be returned to China." 67 This statement was made before Mao knew Japan would surrender that summer. The general expectation at the time was that it would be at least another year or two before Japan could be defeated. Mao did not commit forces to Taiwan, but he ordered the Communists to fight for Manchuria. While Mao would welcome Taiwan becoming a part of China, he did not see it as being of strategic value, as he did Manchuria.

From 1946 to 1949, no CCP leader made any statement about Taiwan's status. What comments they made were articulated in their newspapers or in Xinhua News Agency reports and editorials. At the time of the February Twenty-eighth incident, the mass uprising against

${ }^{65}$ Editorials, Xinhua ribao, December 2, 4, 5, and 9, 1943; Editorials, Jiefang ribao, December 3 and 10, 1943. 66 "Guanyu muqian guoji xingshi xia dihou renwu de zhishi" [Instructions for underground work behind enemy lines in light of the current international situation], 26 December 1943, in Zhongyang wenxian yanjiushi, comp., Zhonggong zhongyang wenjian xuanji, vol. 14, 13839.

${ }^{67}$ Mao Zedong, " " [On coalition government], in Mao Zedong xuanji [Selected works of Mao Zedong], vol. 3 (Beijing: Renmin chubanshe, 1970), 967. 
the Chinese military administration in Taiwan in 1947, they called for solidarity with the oppressed people of Taiwan and tried to link rhetorically the latter's struggle against the Chiang regime to their own. ${ }^{68}$ For all intents and purposes, the CCP just quietly shifted its position. Instead of seeing Taiwan as a Japanese colony on the same basis as Korea, which the CCP would help to achieve independence, it now treated Taiwan as a part of China. Its new approach reflected the general shift in Chinese opinion after the war. When this adjustment happened, the CCP focused on fiercely contesting mainland China and Manchuria and ignored Taiwan. Chiang confirmed in 1946 that the CCP had not infiltrated Taiwan. ${ }^{69}$

After the tide turned in the Chinese Civil War and the prospect of complete victory loomed, the CCP started to take Taiwan seriously. By spring 1949, Communist forces had won decisively in three massive campaigns, in Manchuria, Beijing and Tianjin, and Huaihai, and they were building up momentum to crush the GMD regime. For the first time, the CCP declared that it must "liberate Taiwan" on March 15, 1949. ${ }^{70}$ Its first attempt to breach Taiwan's peripheral defense, which came to be known as the Battle of Guningtou (古寧頭; on Quemoy) took place in October 1949 and ended in a resounding defeat for the Communist forces. As a result, Mao saw the need to plan painstakingly for the invasion of Taiwan.

68 'Taiwan Zizhi yundong' [Taiwan's autonomy movement], Renmin ribao [People's Daily], March 22, 1947.

69 "Shilüe gaoben," entry for 26 October 1946, 060100-217, 06-00997. Chiang was more concerned about Japanese indoctrination of the population of Taiwan, described as Riben nuhua sixiang.

70 "Yidingyao jiefang Taiwan" [We must liberate Taiwan], accessed October 7, 2016, http://cpc.people.com.cn/BIG5/64162/64170/4467358.html. 
In the meantime, Chiang was transforming Taiwan into a redoubt to resist the Communist efforts to annihilate the Republic of China (ROC) and was trying to secure US support to defend Taiwan. ${ }^{71}$ At this point, the CCP articulated for the first time an appreciation of Taiwan's strategic — but not geostrategic_-value. Taking over Taiwan became important because the CCP needed to extinguish the GMD regime to fully establish its legitimacy. Since the CCP did not have a navy or an air force, it crushed GMD resistance on the mainland first and left Taiwan to become, by default, Chiang's last redoubt. ${ }^{72}$ But the CCP had little doubt that it would take Taiwan. ${ }^{73}$ The United States had by then declared in the China White Paper that it would not interfere in the Chinese Civil War. ${ }^{74}$ This was reaffirmed in January 1950 by President Harry Truman and Secretary of State Dean Acheson (1893-1971), who stated that Taiwan was outside the American global defense perimeter and the United States would not interfere with a Communist takeover. ${ }^{75}$ In other words, even

${ }^{71}$ Lin Tongfa, Yijiusijiu da chetui [The retreat of 1949] (Taipei: Lianjing chubanshe, 2009),46-49.

${ }^{72}$ Odd Arne Westad, Decisive Encounters: The Chinese Civil War, 1946-1950 (Stanford, CA: Stanford University Press, 2003), 299.

${ }^{73}$ Chinese People's Political Consultative Congress circular telegram to the People's Liberation Army, 30 September 1949, in Guo Limin, ed., Zhonggong du tai zhengze zhiliao xuanji (1949-1991) [Selected documents of the Chinese Communist Party's Taiwan policy (1949-1991)], vol. 1 (Taipei: Yongye chubanshe, 1992), 1.

${ }^{74}$ Roderick MacFarquhar, ed., Sino-American Relations, 1949-71 (New York: Praeger, 1972), 67-69.

${ }^{75}$ Nancy Bernkopf Tucker, Uncertain Friendships: Taiwan, Hong Kong, and the United States, 1945-1992 (New York: Twayne, 1994), 30. 
though there were views within the US government in the first half of 1950 that the United States should rethink its policy on Taiwan, the official US position remained clear. ${ }^{76}$ The general expectation was that it was just a matter of time before Taiwan would be incorporated into the PRC.

$<$ A $>$ Elevation to Sacred Territory In early 1950, Mao planned to invade Taiwan later in the summer to stub out the ROC, ${ }^{77}$ whereas Chiang prepared to put up a staunch defense. Even though Mao was consulted and gave his blessings to the North Korean leader before the latter started the Korean War, he had not expected this to impact upon Taiwan. ${ }^{78}$ When North Korea invaded South Korea at the end of June, it caught the United States off guard. Truman responded by ordering the US Navy "to repel any attack on Formosa" and preempt "attacks ... from Formosa on the mainland."79 This was a knee-jerk reaction to ensure the Korean War was contained. He had not reversed US policy toward Taiwan. But to Mao this revealed the United States's real-

\footnotetext{
${ }^{76}$ Jian Chen, China's Road to the Korean War (New York: Columbia University Press, 1994), 113-21.

${ }^{77}$ Sergei N. Goncharov, John W. Lewis, and Xue Litai, Uncertain Partners: Stalin, Mao, and the Korean War (Stanford, CA: Stanford University Press, 1993), 79.

${ }^{78}$ David Tsui, "Chinese Military Intervention into the Korean War" (DPhil thesis, Oxford University, 1998), 84-90.

${ }^{79}$ Harry Truman, Memoirs of Harry S. Truman 1946-52: Years of Trial and Hope (New York: Doubleday, 1956), 334.
} 
imperialist —intention. ${ }^{80}$ Taiwan became more than a loose end of the Chinese Civil War. He now believed the United States had intervened directly to preempt the unification of China. In a formal statement issued in response, Premier Zhou Enlai declared, "That Taiwan belongs to China is a fact that can never be changed." He added, "This is not just a historical fact but has also been confirmed in the Cairo Declaration, the Potsdam Declaration, and the reality since Japan's surrender," and he insisted that China would "liberate" Taiwan from the "American aggressor." 81 Truman's statement triggered a basic change in how the CCP looked at Taiwan, which was transformed into "an inalienable part" of China. ${ }^{82}$

Mao and the PRC did not expect or understand Truman's neutralization statement. From their perspective, Truman's order amounted to an American takeover of Taiwan that preempted the completion of the Communist revolution. ${ }^{83}$ They reacted strongly because they had long suspected the United States supported Chiang and intended to frustrate their revolutionary goal. With Chiang articulating an ambition to retake the mainland, this apparent "reversal" of US policy raised a serious concern: the prospect that the United States would help Chiang contest the legitimacy of the PRC. Hence, even as China made a massive

${ }^{80}$ Mao's speech of 28 June 1959, Zhongyang wenxian yanjiushi, ed., Jianguo yilai Mao Zedong wengao [Writings of Mao Zedong since the founding of the republic], vol. 1 (Beijing: Zhongyang wenxian chubanshe, 1987), 423.

${ }^{81}$ Zhou Enlai's statement dated 28 June 1950, in Guo, Zhonggong du tai zhengze zhiliao xuanji, 3-4.

${ }^{82}$ Telegram from Zhou Enlai to the chairman of the UN Security Council dated 24 August 1950, in Guo, Zhonggong du tai zhengze zhiliao xuanji, 9.

${ }^{83} \mathrm{Wu}$ Xiuquan's statement at the fifth UN Security Council meeting, 28 November 1950, in Guo, Zhonggong du tai zhengze zhiliao xuanji, 19. 
military intervention in Korea, Mao ordered the reinforcement of Guangdong's already strong garrison of three corps by another two to five corps, as he became worried about an American-backed invasion of Guangdong by Chiang's forces. ${ }^{84}$ Mao did not believe Truman's neutralization statement reflected true US intent. Instead, he saw this as a preparation to invade China. ${ }^{85}$ Thus, Taiwan acquired a level of strategic importance that the CCP had not previously accorded it.

Beijing further elevated the importance of Taiwan when the Allied powers worked out a peace treaty to settle the Pacific War the following year. It happened as the Allied powers excluded any representative from China at the San Francisco Conference (1951) and did not require Japan to hand over sovereignty of Taiwan to either Chinese government. With the peace treaty apparently perpetuating the American view that Taiwan's status was unsettled, Beijing raised the stake by declaring for the first time that it had a "sacred duty" to retake Taiwan. ${ }^{86}$ Since Japan did renounce its sovereignty over Taiwan in the San Francisco

${ }^{84}$ Telegram on defense of Guangdong and Guangxi against US-Chiang attacks, and telegram on deployment of forces in south China, both dated 17 November 1950, in Zhongyang wenxian yanjiushi, ed., Jianguo yilai Mao Zedong wengao, 666-68.

${ }^{85}$ Editorial, Renmin ribao, November 30, 1950. This was not changed by Truman's sacking of MacArthur. Having seen the US government openly exclude Korea and Taiwan from its global defense perimeter within the year, Mao could not see the sacking of MacArthur as conclusive evidence that he was wrong to believe the United States intended to attack China. MacArthur was sacked in April 1951, before the San Francisco Peace Conference, which did not dispel Mao's mistrust of US intentions.

${ }^{86}$ Zhou's statement on the Anglo-American draft peace treaty with Japan at the San Francisco Conference, 15 August 1951, in Guo, Zhonggong du tai zhengze zhiliao xuanji, 59. 
Treaty, and since Taiwan remained under Chinese control, albeit that of the "renegade" Chiang regime, Beijing did not need to escalate further.

The PRC government finally transformed Taiwan into "a sacred territory of our country since ancient times" in a Renmin ribao (People's Daily) editorial in July $1954 .{ }^{87}$ Its authoritativeness was confirmed in the 27 th-anniversary speech to commemorate the founding of the Communist army by its head, Zhu De, on August 1, 1954, and by a statement Premier Zhou made at a central government meeting 10 days later. ${ }^{88}$

The immediate causes of this shift were Chiang's efforts to seek a mutual defense treaty with the United States, a development that, from Beijing's perspective, would put Taiwan under American protection. ${ }^{89}$ Mao was so concerned that he tried to preempt this by starting the First Taiwan Strait Crisis (1954-1955). ${ }^{90}$ Even though Mao failed to deter the United States, he gained insights into US policies that proved critical. He ascertained "the extent to which the USA and UK were prepared to go over these islands [i.e., Jinmen and Mazu] and Taiwan," and finally saw that the United States had no intention to support a ROC invasion of the mainland. ${ }^{91}$ This knowledge allowed Mao to shift focus from defending the

${ }^{87}$ Editorial, Renmin ribao, July 23, 1954.

${ }^{88}$ Zhu's statement, 1 August 1954, in Guo, Zhonggong du tai zhengze zhiliao xuanji, 67-68; Zhou's report on diplomacy, 11 August 1954, in Guo, Zhonggong du tai zhengze zhiliao xuanji, 74.

${ }^{89}$ Zhou's report on diplomacy, 11 August 1954, in Guo, Zhonggong du tai zhengze zhiliao xuanji, 71-75.

90 Thomas J. Christensen, Useful Adversaries: Grand Strategy, Domestic Mobilization, and Sino-American Conflict, 1947-1958 (Princeton, NJ: Princeton University Press, 1996), 195. ${ }^{91}$ Tsang, Cold War's Odd Couple, 139-40. 
PRC against the United States to pressing on with ambitious domestic changes, culminating in the launch of the Great Leap Forward. ${ }^{92}$ Thus, while Mao never gave up on Taiwan, he parked the issue for the rest of his rule. The Second Taiwan Strait Crisis of 1958 was not a prelude to an invasion of Taiwan. As international relations scholar Thomas Christensen explained, it was started to galvanize the nation to support a highly ambitious policy (the Great Leap Forward) to catapult the PRC to modernity. ${ }^{93}$ Mao ended it when he no longer needed it. He saw a strategic value in Taiwan, but not a geostrategic one — and not one so significant that he would risk a war with the United States over it.

The impact Truman's neutralization policy had on Taiwan was no less significant. With the benefit of hindsight, it was a godsend to Taipei, as it preempted an imminent PRC invasion. This was not how Chiang saw it at the time, however. At first he resented the statement, thinking Truman had "ignored China's sovereignty over Taiwan" and treated Taiwan as if it were an American colony. ${ }^{94}$ Chiang did, nonetheless, take the Truman statement at face value and recognize that the United States would not support him to

\footnotetext{
92 The fact that Mao did not push for a war with the United States over Taiwan is not sufficient to prove Mao did not care very much about Taiwan, as it has been argued by Friedman, "Peace or War with Taiwan in China's Foreign Policy." There was an enormous military gap between the United States and the PRC in the 1950s, and pursuing war with the United States would have risked the obliteration of the PRC. Thus, Mao not seeing Taiwan as worth having the PRC obliterated does not mean Mao did not see Taiwan as being of strategic value.

${ }^{93}$ Christensen, Useful Adversaries, 194-241.

94 "Jiang Jieshi riji," entries for 28 and 29 June 1950.
} 
recapture the mainland.$^{95}$ While he did not give up the dream of reconquering the mainland, he seized on the opportunity Truman's statement offered ${ }^{96}$ Chiang used the idea of a counterattack "primarily to achieve other goals," the most important of which was to secure US aid to ensure the survival of the ROC. ${ }^{97}$ Indeed, he devoted himself to implementing reforms to revitalize governance, defense, and economic capacity. Within weeks, Chiang shifted focus from making a military last stand to forming "a new leadership team ... in charge of rebuilding the party." 98 The successful reform was critical to securing a mutual defense pact with the United States to ensure the PRC could not invade, in repressing local demands for democratic self-government leading to independence, and in deterring the Western great powers from making Taiwan an independent country. ${ }^{99}$ The last was an option both the US and British governments examined in the early 1950s. They ditched it, as it would have required overpowering Chiang's increasingly disciplined and well-trained

${ }^{95}$ Minutes of a meeting among French, British, and American representatives, 3 August 1950, in United States Department of State, Historical Office, Foreign Relations of the United States 1950, vol. 6, East Asia and the Pacific (Washington, DC: US Government Printing Office, 1976), 408.

${ }^{96}$ Steve Tsang, "Chiang Kai-shek and the Kuomintang's Policy to Reconquer the Chinese Mainland, 1949-1958," in Steve Tsang, ed., In the Shadow of China: Political Developments in Taiwan since 1949 (London: C. Hurst, 1993), 48-72.

${ }^{97}$ Hsiao-ting Lin, Accidental State: Chiang Kai-shek, the United States, and the Making of Taiwan (Cambridge, MA: Harvard University Press, 2016), 225.

${ }^{98}$ Linda Chao and Ramon H. Myers, The First Chinese Democracy: Political Life in the Republic of China on Taiwan (Baltimore: Johns Hopkins University Press, 1998), 25.

${ }^{99}$ Tsang, Cold War's Odd Couple, 84-99. 
garrison, half a million strong. By insisting that Taiwan was a part of China, Chiang unwittingly reinforced the PRC's claim over Taiwan. As a result, the fate of Taiwan become tied to that of the ROC: the people of Taiwan could not decide their own future and what to call their state even after democratization.

\section{$<\mathrm{A}>$ Implication}

The transformation of the CCP's view of Taiwan, from seeing it as a Japanese colony to be given independence to seeing it, successively, as a Chinese territory of peripheral significance, as an inalienable part of China, and finally (between 1943 and 1954) as a sacred territory happened as events unfolded in the Pacific War, the Chinese Civil War, and the Cold War. The CCP changed its policy toward Taiwan largely in response to unforeseen events. From 1949 to 1950, Taiwan took on strategic importance as it became, by default, the last holdout against the CCP establishing undisputed control over the whole of China, at a time when most of the world recognized Chiang's regime as the government of China. The CCP elevated Taiwan to a matter of central interest only after Truman's instinctive response to the Korean War forced the PRC to postpone indefinitely its plan to invade Taiwan and put an end to the ROC. ${ }^{100}$ The Chinese responses were not based on the geographical dimension of Taiwan's new strategic value, even though it happened at a time when General MacArthur articulated most graphically Taiwan's geostrategic significance - to the United States.

\footnotetext{
${ }^{100}$ Christopher P. Twomey, The Military Lens: Doctrinal Difference and Deterrence Failure in Sino-American Relations (Ithaca, NY: Cornell University Press, 2010), 194-95.
} 
MacArthur's statement was regularly misconstrued by the Chinese to imply that Taiwan would be used as an "unsinkable aircraft carrier" against China. ${ }^{101}$ What MacArthur actually said was the opposite, viz. if Taiwan were held by forces hostile to the United States in a new world war, it "could be compared to an unsinkable aircraft carrier and submarine tender ideally located to accomplish offensive strategy and at the same time checkmate defensive or counteroffensive operations by friendly forces based on Okinawa and the Philippines." 102

While the geostrategic dimension MacArthur put forth could not have been lost on Chinese policy makers, it was the Chinese perception of the Truman statement that brought about the basic change in the PRC's policy. The views and actions of the people of Taiwan were irrelevant in this transformation. With slight naval and air capabilities and no doctrine by which to project naval or air power, the PRC itself could not use Taiwan in the way MacArthur envisaged and did not attach strategic value to Taiwan's location in the 1950s. The reality is that Beijing looked at Taiwan afresh as a result of shifts in Cold War politics. Events of the 1950s led to Taiwan being reimagined in the geography of China. It was because the Chinese Civil War could not be concluded and was merged into the Cold War that Beijing attached strategic value to Taiwan. But Mao was not willing to go to war with the United States over Taiwan, a war that Mao knew China could not win.

${ }^{101}$ People's Daily Online, March 16, 2000, accessed October 19, 2016, http://www.fas.org/news/china/2000/eng20000316N101.htm.

102 Douglas MacArthur to C. A. Lewis, 20 August 1950, Papers of Douglas MacArthur, RG6, FECOM, General Files, Formosa file, Douglas MacArthur Memorial Library, Norfolk, VA. 
This valuation might have changed as the Cold War ended and the ROC government gave up the pretentious claim of sovereignty over the Chinese mainland in the early 1990s, after both Chiang Kai-shek and Chiang Ching-kuo had died. But by then the PRC had chosen to add a geographical dimension to the strategic importance of Taiwan. This development reflected military modernization, strategic shifts, and changes in maritime doctrine of the PRC that started in the 1980s, as well as a steady rise of Chinese power and ambition. The introduction of a new strategic concept called the "first island chain"-which put Taiwan in a pivotal place in this maritime defense line - and the commitment to build up a blue water navy made Taiwan geostrategically significant to the PRC for the first time. This new doctrine chimed with MacArthur's description of Taiwan as a potential unsinkable aircraft carrier for the PRC. Taiwan's geography thus became a significant consideration. As the PRC continues to rise, builds up its naval and airpower, and takes a more assertive approach, Taiwan's geostrategic importance increases.

\section{$<\mathrm{A}>$ Conclusions}

This paper shows that Taiwan was not elevated to sacred status because of a sudden recognition of Taiwan's geostrategic significance. The PRC government described Taiwan as "a sacred territory" when the United States prevented it from taking Taiwan but before it accorded geostrategic value to Taiwan. Needless to say, the two are not mutually exclusive but they are not interchangeable either.

What this paper has demonstrated is that, while the PRC government attaches geostrategic importance to Taiwan today, neither it nor its predecessor did so historically. This transformation was driven by a change in the ambition and military capabilities of China. The dramatic shifts in the way successive governments of China viewed the status of Taiwan over the last 150 years happened as a result of unforeseen events and not because of 
strategic importance inherent in Taiwan's location. Even after Mao elevated Taiwan to sacred status, he failed to see a compelling need to incorporate Taiwan once he realized that Chiang could not get US support to attack the mainland and would not tolerate Taiwan independence. Taiwan took on significant strategic value in the Maoist period mainly because Mao was concerned that Chiang could gain American backing to challenge the legitimacy of the PRC.

The emergence of a geographic dimension to the strategic importance of Taiwan happened in the post-Mao era. This was caused by the replacement of the Maoist doctrine of a people's war (luring an invader deep into the mainland to then destroy it) with forward maritime defense and the building up of capabilities to hold the first island chain, of which Taiwan is a key component. Beijing began to see geostrategic importance in Taiwan because of capability enhancement, new doctrinal development, and a desire to be more assertive.

The PRC's contemporary assessment of Taiwan's geostrategic value is driven by the ambition and strategic vision of its leadership. That dynamic has applied most particularly since Xi Jinping became leader of China. Xi informed US Secretary of State John Kerry (1943-) of his view in 2015 by saying: "The broad Pacific Ocean is vast enough to embrace both China and the United States." 103 For the PRC, therefore, it becomes essential to incorporate Taiwan into the first island chain rather than only to secure the Western extremity of the Pacific Ocean. History — and, for that matter, geography—-has merely been conscripted to "serve the people," as an old Maoist adage goes. In assessing the geostrategic significance of Taiwan to the PRC today, it is important to put this in context. Taiwan's importance to China is not based on an immutable geographical factor but rather on contemporary strategic

103 AFP, "Pacific Ocean Big Enough for China, US: Xi," Australian, May 15, 2015, accessed September 10, 2019, https://www.theaustralian.com.au/business/latest/pacific-ocean-bigenough-for-china-us-xi/news-story/d5e8555c014c46f2a637aac826ed05a0. 
calculations that can change if the regime itself is replaced or, for that matter, if China's government no longer subscribes to the maritime strategy of the first island chain.

\section{$<\mathrm{A}>$ Notes on Contributor}

Steve Tsang is Professor of Chinese Studies and Director of the China Institute at SOAS University of London. He is also an Emeritus Fellow of St Antony's College, Oxford, and an Associate Fellow of the Chatham House. He works on the modern history, politics, and external policy of China, Taiwan, and Hong Kong. He is the author of five and the editor of thirteen books, including eight on Taiwan.

Correspondence to: Steve Tsang. Email: st82@soas.ac.uk. 